Fakultas Komputer

Klarisa Anugrah

TUGAS 1 - 88675543

BORDER GATEWAY PROTOKOL

\author{
Klarisa Anugrah \\ 175100018 \\ Fakultas Komputer \\ Klarisaanugrah.student@umitra.ac.id
}

\begin{abstract}
BGP (Border Gateway Protocol) adalah sebuah protokol routing inter-Autonomous System dan salah satu jenis routing protokol yang banyak digunakan di ISP besar (Telkomsel) ataupun perbankan, Fungsi utama sistem BGP adalah untuk bertukar informasi network yang dapat dijangkau (reachability) oleh sistem BGP lain, termasuk di dalamnya informasi-informasi yang terdapat dalam list autonomous system (AS). BGP berjalan melalui sebuah protokol transport, yaitu

TCP. AS (Autonomous System), menurut definisi klasik adalah seperangkat router yang berada di bawah otoritas/administrasi teknis tunggal. Untuk merutekan paket antar-AS internal, kita akan membutuhkan Interior Gateway Protocol. Sementara untuk merutekan paket ke AS lain, kita membutuhkan Exterior Gateway Protocol. BGP mempunyai skalabilitas yang tinggi karena dapat melayani pertukaran routing pada beberapa organisasi besar. Oleh karena itu BGP dikenal dengan routing protokol yang sangat rumit dan kompleks. Setiap orang yang menggunakan internet memiliki paling sedikit satu nomor unik AS (Autonomous System), dan mereka menggunakan BGP untuk menyebarkan jaringan mereka kepada jaringan peer/tetangga. Routing BGP adalah protokol path-vector. Oleh karena itu, BGP mengadvertise hanya jalur yang diperlukan untuk mencapai tujuan tertentu. BGP tidak menjelaskan bagaimana sebuah paket akan dirutekan dalam suatu AS, tidak seperti yang dilakukan OSPF. BGP dapat disebut protokol distance-vector karena memiliki kesamaan walaupun sedikit.Hal tersebut dapat terjadi karena belum terintegrasinya antara bagian keuangan dan administrasi sehingga penyajian laporan yang dibuat menjadi tidak sama. Untuk itu perlunya usulan sistem yang berbasis jaringan untuk mendukung pengolahan data penerimaan dan pengeluaran kas sehingga penyajian laporan dapat dilakukan secara terstruktur.
\end{abstract}

Kata Kunci : Border Gateway Protokol.

A. PENDAhuluan
BGP (Border Gateway Protocol) adalah sebuah protokol routing inter- 


\section{Fakultas Komputer}

\section{TUGAS 1 - 88675543}

Autonomous System dan salah satu jenis routing protokol yang banyak digunakan di ISP besar (Telkomsel) ataupun perbankan, Fungsi utama sistem BGP adalah untuk bertukar informasi network yang dapat dijangkau (reachability) oleh sistem BGP lain, termasuk di dalamnya informasi-informasi yang terdapat dalam list autonomous system (AS). BGP berjalan melalui sebuah protokol transport, yaitu TCP. AS (Autonomous System), menurut definisi klasik adalah seperangkat router yang berada di bawah otoritas/administrasi teknis tunggal. Untuk merutekan paket antar-AS internal, kita akan membutuhkan Interior Gateway Protocol. Border Gateway Protocol disingkat BGP adalah inti dari protokol routing internet. Protocol ini yang menjadi backbone dari jaringan internet dunia. BGP adalah protokol routing inti dari internet yg digunakan untuk melakukan pertukaran informasi routing antar jaringan.

\section{B. PEMBAHASAN / STUDI KASUS}

A. Pengertian Routing BGP BGP (Border Gateway Protocol) merupakan routing protocol jenis EGP (Exterior Gateway Protocol) . BGP adalah salah satu routing protocol yang menangani jaringan antar AS (Autonomous System). BGP memiliki kemampuan yang sangat handal dengan melakukan pengumpulan rute, pertukaran rute dan

\section{Klarisa Anugrah}

menentukan jalur terbaik untuk mencapai tujuan.

BGP merupakan metode routing untuk tingkat jaringan yang besar dan rumit yang disetting secara dynamic guna mempermudah dan mempercekat dalam pengkonfigurasiannya. BGP dapat digunakan untuk menghubungkan antar dua organisasi besar yang memiliki AS yang berbeda. Tujuan BGP adalah untuk memperkenalkan pada dunia luar alamat-alamat IP apa saja yang ada dalam jaringan tersebut. Setelah dikenal dari luar, server-server, perangkat jaringan, PC-PC dan perangkat komputer lainnya yang ada dalam jaringan tersebut juga dapat dijangkau dari dunia luar. Selain itu, informasi dari luar juga dikumpulkannya untuk keperluan organisasi tersebut berkomunikasi dengan dunia luar.

Dengan mengenal alamatalamat IP yang ada di jaringan lain, maka para pengguna dalam jaringan Anda juga dapat menjangkau jaringan mereka. Sehingga terbukalah halaman web Yahoo, search engine Google, toko buku Amazon, dan banyak lagi. Border Gateway Protocol disingkat BGP adalah inti dari protokol routing internet. Protocol ini yang menjadi backbone dari jaringan internet dunia. BGP adalah protokol 


\section{Fakultas Komputer}

\section{TUGAS 1 - 88675543}

routing inti dari internet yg digunakan untuk melakukan pertukaran informasi routing antar jaringan. BGP dijelaskan dalam RFC 4271. RFC 4276 menjelaskan implementasi report pada BGP-4, RFC 4277 menjelaskan hasil ujicoba penggunaan BGP-4. Ia bekerja dengan cara memetakan sebuah tabel IP network yang menunjuk ke jaringan yg dapat dicapai antar Autonomous System (AS). Hal ini digambarkan sebagai sebuah protokol path vector. BGP tidak menggunakan metrik IGP (Interior Gateway Protocol) tradisional, tapi membuat routing decision berdasarkan path, network policies, dan atau ruleset. dari Januari 2006 hingga saat ini BGP versi 4 masih digunakan. BGP mendukung Class InterDomain Routing dan menggunakan route aggregation untuk mengurangi ukuran tabel routing. sejak tahun 1994, BGP-4 telah digunakan di internet. semua versi dibawahnya sudah tidak digunakan. BGP diciptakan untuk menggantikan protokol routing EGP yang mengijinkan routing secara tersebar sehingga tidak harus mengacu pada satu jaringan backbone saja.

B. Jenis-Jenis Routing BGP Routing protokol BGP dibagi menjadi dua subbagian besar yang berbeda berdasarkan

\section{Klarisa Anugrah}

fungsi, lokasi berjalannya sesi BGP, dan kebutuhan konfigurasinya yaitu: 1. IBGP (Internal BGP) Sesuai dengan namanya, Internal BGP atau IBGP adalah sebuah sesi BGP yang terjalin antara dua router yang menjalankan BGP yang berada dalam satu hak administrasi, atau dengan kata lain berada dalam satu autonomous system yang sama. Sesi internal BGP biasanya dibangun dengan cara membuat sebuah sesi BGP antarsesama router internal dengan menggunakan nomor AS yang sama. Biasanya IBGP berguna untuk memungkinkan router internal saling bertukar rute-rute yang didapat dari dunia luar. Dengan demikian semua router saling dapat mengetahui rute-rute apa saja yang disimpan oleh masing-masing router. Setelah mengetahui lebih banyak rute, maka jalan menuju ke suatu situs di internet memiliki banyak pilihan. IBGP biasanya digunakan pada jaringan internal ISP atau perusahaan-perusahaan besar. Tujuannya adalah agar antarsesama router di dalamnya dapat saling bertukar informasi yang didapat dari dunia luar, atau dengan kata lain dari AS number lain. Untuk menjalankan IBGP dalam jaringan internal, sebuah sesi IBGP memerlukan bantuan routing protocol yang lain. 


\section{Fakultas Komputer}

\section{TUGAS 1 - 88675543}

Tujuannya adalah agar router tetangga yang menjadi tujuan sesi IBGP dapat dicapai oleh router tersebut. Hal ini diperlukan karena untuk membuka sebuah sesi BGP diperlukan reachability ke tetangga tujuannya. Sebuah sesi IBGP antardua buah router atau lebih tidak memerlukan koneksi secara langsung, atau dengan kata lain tidak memerlukan koneksi Point-to-Point. Kita bisa membangun sesi IBGP antar dua router meskipun keduanya berada dalam jarak yang jauh, asalkan tidak terpisah dalam autonomous system yang lain. Namun syarat untuk membuatnya demikian adalah desain dan implementasi internal routing protocol yang baik. Internal routing protocol sangat berguna untuk melakukan routing terhadap paket-paket komunikasi BGP sehingga bisa sampai dari router asal ke router tujuannya. 2. EBGP (External BGP) Kebalikannya dari IBGP, External BGP atau sering disingkat EBGP berarti sebuah sesi BGP yang terjadi antar dua router atau lebih yang berbeda autonomous systemnya atau berbeda hak administratif. Tidak hanya sekadar beda nomor AS saja, namun benarbenar berbeda administrasinya. Jadi misalnya router Kita dengan router ISP ingin dapat saling bertukar informasi

\section{Klarisa Anugrah}

dengan menggunakan bantuan BGP, maka kemungkinan besar Kita akan membuat sesi EBGP. Hal ini dikarena autonomous system router Kita dengan router ISP dibuat berbeda. Pihak ISP tentu tidak akan memasukkan router BGP Kita dalam autonomous systemnya karena memang bukan hak dan kewajiban mereka untuk mengurus router Kita. Dengan perbedaan autonomous system ini, maka seperangkat peraturan saat melakukan routing update tentu berbeda dengan apa yang ada dalam IBGP. Untuk itulah sesi BGP jenis ini dikategorikan berbeda, yaitu sebagai External BGP. Sesi External BGP biasanya dibuat dengan menggunakan bantuan media point-to-point seperti misalnya line Point-toPoint serial, satelite Point-toPoint, wireless Point-to-Point, dan banyak lagi. Sesi EBGP biasanya terjadi pada router yang letaknya berada di perbatasan antara jaringan Kita dengan jaringan lain, atau sering disebut juga dengan istilah border router. Tujuan utama dibuatnya EBGP adalah untuk memudahkan pendistribusian informasi routing dari pihak luar ke jaringan kita.

C. Karakteristik BGP 1. Menggunakan algoritma routing distance vektor.Algoritma routing distance vector secara periodik 


\section{Fakultas Komputer}

\section{TUGAS 1 - 88675543}

menyalin table routing dari router ke router. Perubahan table routing di update antar router yang saling berhubungan pada saat terjadi perubahan topologi;

2. Digunakan antara ISP dengan ISP dan client-client; 3. Digunakan untuk merutekan trafik internet antar autonomous system; 4. BGP adalah Path Vector routing protocol.Dalam proses menentukan rute-rute terbaiknya selalu mengacu kepada path yang terbaik dan terpilih yang didapatnya dari router BGP yang lainnya; 5. Router BGP membangun dan menjaga koneksi antarpeer menggunakan port nomor 179 ;

6. Koneksi antar-peer dijaga dengan menggunakan sinyal keepalive secara periodic; 7. Metrik (atribut) untuk menentukan rute terbaik sangat kompleks dan dapat dimodifikasi dengan fleksibel; 8. BGP memiliki routing table sendiri yang biasanya memuat prefiks-prefiks routing yang diterimanya dari router BGP lain.

D. Cara Kerja BGP Routing protokol BGP baru dapat dikatakan bekerja pada sebuah router jika sudah terbentuk sesi komunikasi dengan router tetangganya yang juga menjalankan BGP. Sesi komunikasi ini adalah

\section{Klarisa Anugrah}

berupa komunikasi dengan protokol TCP dengan nomor port 179. Setelah terjalin komunikasi ini, maka kedua buah router BGP dapat saling bertukar informasi rute. Untuk berhasil menjalin komunikasi dengan router tetangganya sampai dapat saling bertukar informasi routing, ada beberapa hal yang perlu diperhatikan: 1. Kedua buah router telah dikonfigurasi dengan benar dan siap menjalankan routing protokol BGP.

2. Koneksi antarkedua buah router telah terbentuk dengan baik tanpa adanya gangguan pada media koneksinya. 3. Pastikan paket-paket pesan BGP yang bertugas membentuk sesi BGP dengan router tetangganya dapat samp dengan baik ke tujuannya. 4. Pastikan kedua buah router BGP tidak melakukan pemblokiran port komunikasi TCP

179.

5. Pastikan kedua buah router tidak kehabisan resource saat sesi BGP sudah terbentuk dan berjalan.

E. Paket-Paket Pada Protokol BGP

Untuk membentuk dan mempertahankan sebuah sesi BGP dengan router tetangganya, BGP mempunyai mekanismenya sendiri yang unik. Pembentukan sesi BGP ini mengkitalkan paket-paket 
Fakultas Komputer

\section{TUGAS 1 - 88675543}

pesan yang terdiri dari empat macam. Paket-paket tersebut adalah sebagai berikut: 1. Open Message

Sesuai dengan namanya, paket pesan jenis ini merupakan paket pembuka sebuah sesi BGP. Paket inilah yang pertama dikirimkan ke router tetangga untuk membangun sebuah sesi komunikasi. Paket ini berisikan informasi mengenai BGP version number, AS number, hold time, dan router ID. 2. Keepalive Message Paket Keepalive message bertugas untuk menjaga hubungan yang telah terbentuk antarkedua router BGP. Paket jenis ini dikirimkan secara periodik oleh kedua buah router yang bertetangga. Paket ini berukuran 19 byte dan tidak berisikan data sama sekali. 3. Notification Message Paket pesan ini adalah paket yang bertugas menginformasikan error yang terjadi terhadap sebuah sesi BGP. Paket ini berisikan fieldfield yang berisi jenis error apa yang telah terjadi, sehingga sangat memudahkan penggunanya untuk melakukan troubleshooting.

4. Update Message Paket update merupakan paket pesan utama yang akan membawa informasi rute-rute yang ada. Paket ini berisikan semua informasi rute BGP yang ada dalam jaringan

\section{Klarisa Anugrah}

tersebut. Ada tiga komponen utama dalam paket pesan ini, yaitu Network-Layer

Reachability Information (NLRI), path attribut, dan withdrawn routes.

F. Atribut-Atribut BGP Salah satu ciri khas dan juga merupakan kekuatan dari routing protokol BGP ada pada atribut-atribut pendukungnya. Atribut-atribut ini yang nantinya digunakan sebagai parameter untuk menentukan jalur terbaik untuk menuju ke suatu situs. Atribut ini juga dapat mengatur keluar masuknya routing update dari router-router BGP tetangga. Dengan mengatur atribut ini, Kita dapat dengan bebas mengatur bagaimana karakteristik dan sifat dari sesi BGP tersebut. Untuk melayani Kita mengatur dengan sebebas-bebasnya, tersedia 10 macam atribut BGP yang umum ditambah satu atribut BGP yang hanya ada pada produk-produk Cisco. Masing-masing memiliki ciri khas dan tugasnya tersendiri untuk memungkinkan Kita memanajemen routing update dan traffic yang keluar masuk. Atribut-atribut BGP tersebut adalah sebagai berikut: $1 . \quad$ Origin Atribut BGP yang satu ini merupakan atribut yang termasuk dalam jenis Well known mkitatory. Jika 


\section{Fakultas Komputer}

\section{TUGAS 1 - 88675543}

sumbernya berasal router BGP dalam jaringan lokal atau menggunakan asnumber yag sama dengan yang sudah ada, maka indicator atribut ini adalah huruf " $\mathrm{i}$ " untuk interior. Apabila sumber rute berasal dari luar jaringan lokal, maka tkitanya adalah huruf "e" untuk exterior. Sedangkan apabila rute didapat dari hasil redistribusi dari routing protokol lain, maka tkitanya adalah "?" yang artinya adalah incomplete.

2.

AS_Path

Atribut ini harus ada pada setiap rute yang dipertukarkan menggunakan BGP. Atribut ini menunjukkan perjalanan paket dari awal hingga berakhir di tempat Kita. Perjalanan paket ini ditunjukkan secara berurut dan ditunjukkan dengan menggunakan nomor-nomor AS. Dengan demikian, akan tampak melalui mana saja sebuah paket data berjalan ke tempat

Kita. $3 . \quad$ Next Hop

Next hop sesuai dengan namanya, merupakan atribut yang menjelaskan ke mana selanjutnya sebuah paket data akan dilemparkan untuk menuju ke suatu lokasi. Dalam EBGP-4, yang menjadi next hop dari sebuah rute adalah alamat asal (source address) dari sebuah router yang mengirimkan prefix tersebut dari luar AS. Dalam IBGP-4, alamat yang menjadi parameter

\section{Klarisa Anugrah}

next hop adalah alamat dari router yang terakhir mengirimkan rute dari prefix tersebut. Atribut ini juga bersifat Wellknown Mkitatory. 4. Multiple Exit Discriminator (MED)

Atribut ini berfungsi untuk menginformasikan router yang berada di luar AS untuk mengambil jalan tertentu untuk mencapat si pengirimnya. Atribut ini dikenal sebagai metrik eksternal dari sebuah rute. Meskipun dikirimkan ke AS lain, atribut ini tidak dikirimkan lagi ke AS ketiga oleh AS lain tersebut. Atribut ini bersifat Optional Nontransitive.

5. Local Preference Atribut ini bersifat Wellknown Discretionary, di mana sering digunakan untuk memberitahukan router-router BGP lain dalam satu AS ke mana jalan keluar yang diprefer jika ada dua atau lebih jalan keluar dalam router tersebut. Atribut ini merupakan kebalikan dari MED, di mana hanya didistribusikan antarrouter-router dalam satu AS saja atau router IBGP lain. 6. Atomic Aggregate Atribut ini bertugas untuk memberitahukan bahwa sebuah rute telah diaggregate (disingkat menjadi pecahan yang lebih besar) dan ini menyebabkan sebagian informasi ada yang hilang. Atribut ini bersifat Wellknown 
Fakultas Komputer

\section{TUGAS 1 - 88675543}

Discretionary.

7.

Aggregator

Atribut yang satu ini berfungsi untuk memberikan informasi mengenai Router ID dan nomor Autonomous System dari sebuah router yang melakukan aggregate terhadap satu atau lebih rute. Parameter ini bersifat Optional Transitive. $8 . \quad$ Community Community merupakan fasilitas yang ada dalam routing protokol BGP-4 yang memiliki kemampuan memberikan tag pada rute-rute tertentu yang memiliki satu atau lebih persamaan. Dengan diselipkannya sebuah atribut community, maka akan terbentuk sebuah persatuan rute dengan tag tertentu yang akan dikenali oleh router yang akan menerimanya nanti. Setelah router penerima membaca atribut ini, maka dengan sendirinya router tersebut mengetahui apa maksud dari tag tersebut dan melakukan proses sesuai dengan yang diperintahkan. Atribut ini bersifat Optional Transitive. 9. Originator ID Atribut ini akan banyak berguna untuk mencegah terjadinya routing loop dalam sebuah jaringan. Atribut ini membawa informasi mengenai router ID dari sebuah router yang telah melakukan pengiriman routing. Jadi dengan adanya informasi ini, routing yang telah dikirim oleh

\section{Klarisa Anugrah}

router tersebut tidak dikirim kembali ke router itu. Biasanya atribut ini digunakan dalam implementasi route reflector. Atribut ini bersifat Optional Nontransitive.

10. Cluster list

Cluster list merupakan atribut yang berguna untuk mengidentifikasi router-router mana saja yang tergabung dalam proses route reflector. Cluster list akan menunjukkan path-path atau jalur mana yang telah direfleksikan, sehingga masalah routing loop dapat dicegah. Atribut ini bersifat Optional Nontransitive. $11 . \quad$ Weight

Atribut yang satu ini adalah merupakan atribut yang diciptakan khusus untuk penggunaan di router keluaran vendor Cisco. Atribut ini merupakan atribut dengan priority tertinggi dan sering digunakan dalam proses path selection. Atribut ini bersifat lokal hanya untuk digunakan pada router tersebut dan tidak diteruskan ke router lain karena belum tentu router lain yang bukan bermerk Cisco dapat mengenalinya. Fungsi dari atribut ini adalah untuk memilih salah satu jalan yang diprioritaskan dalam sebuah router.

Ketika ada dua buah jalan keluar, maka dengan memodifikasi atribut Weight ini, router dapat memilih salah satu jalan untuk diprioritaskan 


\section{Fakultas Komputer}

\section{TUGAS 1 - 88675543}

sebagai jalan keluar. Jadi Kita dapat mengatur dengan leluasa jalan mana yang akan digunakan. Weight tidak digunakan pada router lain selain Cisco. Bagaimana Proses Path Selection (Pemilihan Jalur Terbaik) dalam BGP? Setelah Anda mengenal semua jenis atribut dan kegunaannya, kini saatnya untuk mengetahui bagaimana atribut-atribut tersebut digunakan untuk proses pemilihan jalan terbaik menuju suatu lokasi. Mengapa perlu dilakukan pemilihan rute terbaik? Kapan proses pemilihan rute terbaik dilakukan oleh BGP? Router Anda perlu melakukan pemilihan rute terbaik ketika mendapatkan dua atau lebih rute untuk menuju ke suatu lokasi di luar. Biasanya sebuah router BGP mungkin saja mendapatkan sebuah rute lebih dari dua, tergantung pada banyaknya sesi BGP yang dibentuk dengan tetanggatetangganya. Semakin banyak sesi BGP dengan router tetangga, maka router tetangga tersebut akan mengirimkan banyak rute yang diketahuinya, sehingga mungkin saja ada yang sama. Ketika dihadapkan pada dua jalan dengan tujuan yang sama, maka tugas router BGP adalah harus memilih salah satu jalan untuk digunakan meneruskan informasi yang dibawanya.

\section{Klarisa Anugrah}

Jalan yang dipilih haruslah jalan yang terbaik yang ada saat itu untuk dapat meneruskan informasi sebaik mungkin. Untuk memilih salah satu jalan tersebut, router BGP akan langsung menjalankan prosedur pemilihan rute terbaik atau yang sering disebut dengan istilah path selection. Dalam proses pemilihan jalur terbaik atau path selection, atribut-atribut yang telah dijelaskan di ataslah yang sangat berperan penting. Semua atribut tersebut memiliki tingkat prioritasnya sendiri dalam proses penentuan jalur terbaik. Maksudnya ketika ada dua rute menuju ke lokasi www.yahoo.com masingmasing memiliki atribut $\mathrm{B}$ dan C, maka router BGP akan membandingkan nilai $\mathrm{B}$ dengan C. Jika ternyata nilai $\mathrm{B}$ yang lebih baik, maka rute menuju ke www.yahoo.com adalah rute yang beratribut B. Rute tersebut akan dijadikan sebagai jalur terbaik dan semua traffic menuju www.yahoo.com akan dilarikan melalui jalur B. Sedangkan rute yang memiliki atribut $\mathrm{C}$ dijadikan sebagai back-up. Back-up ini akan digunakan suatu saat ketika rute yang beratribut $\mathrm{B}$ tadi sedang bermasalah. Jadi rute yang tidak terpilih bukan berarti diabaikan begitu saja. Mekanisme inilah yang merupakan salah satu 
Fakultas Komputer

\section{TUGAS 1 - 88675543}

kehebatan dari BGP.

Proses path selection ke sebuah

lokasi yang terjadi dalam sebuah sesi BGP hingga menemukan sebuah jalur terbaik adalah sebagai berikut: 1. Jika hanya ada sebuah rute menuju ke lokasi A, maka rute tersebutlah yang pasti dijadikan rute terbaik dan akan langsung digunakan.

2. Jika ada dua buah rute menuju ke lokasi A, maka router BGP akan menggunakan atribut WEIGH untuk memilih rute mana yang paling baik. Rute dengan nilai WEIGH yang paling tinggi akan dipilih sebagai jalur terbaik. 3. Jika nilai weight keduanya sama, maka router akan menggunakan atribut LOCAL PREFERENCE sebagai bahan pembanding. Rute dengan nilai LOCAL PREFERENCE yang paling tinggi adalah rute yang terpilih sebagai rute terbaik. 4. Jika nilai local preference sama, maka sebagai bahan pembanding router BGP akan memeriksa rute mana yang berasal dari dirinya sendiri. Jika rute tersebut berasal dari dirinya sendiri maka rute tersebut yang akan dijadikan rute terbaik. 5. Jika rute menuju A bukan berasal dari dirinya, maka router akan menggunakan atribut AS_PATH untuk mencari rute terbaik. Rute dengan atribut AS_PATH terpendek akan dipilih sebagai

\section{Klarisa Anugrah}

rute terbaik.

6. Apabila atribut AS_PATH

nya sama, maka atribut selanjutnya yang digunakan untuk memilih jalan terbaik adalah ORIGIN. Atribut ORIGIN terdiri parameter IGP, EGP dan Incomplete. Parameter dengan nilai referensi terendah yang akan dipilih menjadi rute terbaik. IGP memiliki nilai referensi paling rendah, disusul EGP dan akhirnya Incomplete. Rute dengan atribut ORIGIN IGP akan lebih dipilih daripada EGP atau Incomplete, begitu seterusnya hingga rute dengan atribut Incomplete menjadi rute yang berada di urutan paling belakang.

7. Jika atribut Origin pada rute-rute tersebut sama, maka atribut selanjutnya yang digunakan adalah MED (Multi Exit Discriminator). MED merupakan atribut untuk memungkinkan Anda memilih jalan mana yang paling baik untuk menuju sebuah situs. Jenisnya kurang lebih sama seperti Local Preference, namun bedanya atribut MED ini hanya disebarkan dalam satu AS yang sama saja. Atribut ini tidak dikirimkan ke luar AS dari router BGP tersebut. Biasanya atribut ini banyak digunakan jika sebuah router memiliki dua atau lebih jalan yang sama namun menuju ke satu ISP. Rute dengan nilai MED yang paling rendah 
Fakultas Komputer

\section{TUGAS 1 - 88675543}

adalah yang terpilih sebagai rute

terbaik.

8. Jika nilai MED pada kedua

rute tersebut sama, maka router

BGP akan melakukan pemilihan berdasarkan jenis sesi BGP dari rute-rute tersebut. Seperti telah dijelaskan diatas, jenis BGP ada dua macam yaitu IBGP dan EBGP. Kedua parameter ini juga digunakan dalam pemilihan jalan terbaik. Sebuah rute yang berasal dari sebuah sesi EBGP memiliki prioritas yang lebih tinggi daripada rute dari sesi IBGP. Jadi rute yang berasal dari sesi EBGP dengan router BGP lain tentu akan dijadikan sebagai rute terbaik. 9. Jika setelah melalui ketentuan diatas, kedua rute tersebut juga masih identik, maka proses path selection selanjutnya adalah menggunakan parameter jalur terdekat dalam jaringan internal untuk menuju ke Next Hop. Maksudnya adalah, router BGP akan membaca atribut Next hop dari kedua jalur tersebut. Setelah diketahui, router tersebut akan memeriksa jalur mana yang memilik Next hop yang terdekat dari router tersebut. Jalur yang diperiksa ini merupakan jalur yang berasal dari routing protokol internal seperti OSPF, EIGRP, atau bahkan statik. Setelah didapatkan rute mana yang memiliki Next hop yang paling dekat dan mudah diakses, maka

\section{Klarisa Anugrah}

rute tesebut langsung dipilih menjadi yang terbaik. 10. Jika prosedur ini masih tidak membuahkan sebuah rute terbaik juga, maka jalan terakhir untuk menemukannya adalah dengan membandingkan BGP ROUTER ID dari masingmasing rute. Sebuah rute pasti akan membawa informasi BGP ROUTER ID dari router asalnya. Parameter inilah yang menjadi pembanding terakhir untuk proses path selection ini. Karena BGP ROUTER ID tidak mungkin sama, maka sebuah jalan terbaik pastilah dapat terpilih. BGP ROUTER ID biasanya adalah alamat IP tertinggi dari sebuah router atau dapat juga berupa IP interface loopback. Router BGP akan memilih rute dengan nilai BGP ROUTER ID yang terendah.

Kekuatan BGP yang lainnya adalah Anda dapat memodifikasi dan mengubah atribut-atribut yang ada pada sebuah rute, sehingga proses pemilihan jalur terbaik ini juga dapat Anda atur. Dengan mengatur proses ini, maka Anda dapat mengatur lalulintas data yang keluarmasuk jaringan

Anda.

G. Kelebihan Routing BGP Beberapa kelebihan routing BGP:

1. BGP memiliki kemampuan untuk mengontrol dan 


\section{Fakultas Komputer}

\section{TUGAS 1 - 88675543}

mengatur trafik-trafik dari sumber berbeda di dalam network multi-home (tersambung ke lebih dari 1 ISP/Internet Service Provider); 2. Sangat sederhana dalam instalasi

H. Kekurangan Routing BGP Beberapa kekurangan routing BGP:

1. BGP mempublikasikan rute yang tidak diketahui bagaimana cara mencapainya; 2. Sangat terbatas dalam mempergunakan topologi.

I. Pengimplementasian Routing BGP Skema Jaringan.

Pengimplementasian

Routing

BGP

Skema Jaringan.

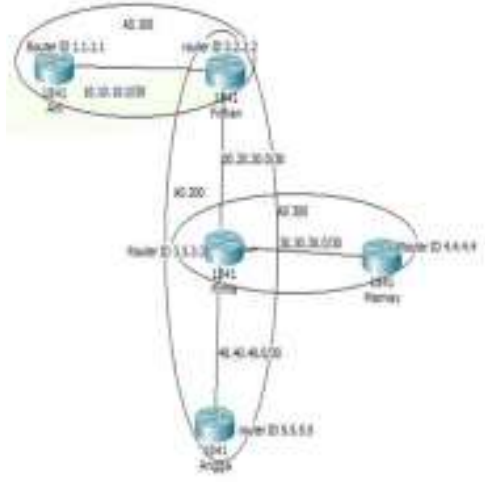

Berikut langkah-langkah untuk mengkonfigurasinya

1. Siapkan mikrotik sebanyak 5

2. Siapkan laptop sebanyak 5;

3. Siapkan kabel straight sebanyak 5 dan kabel cross sebanyak

4

4. Hubungkan kabel straight

\section{Klarisa Anugrah}

dari laptop-mikrotik di ether 2; 5. a. Konfigurasi di mikrotik Ani

[admin@mikrotik] > ip address add address $=10.10 .10 .1 / 30$ interface $=$ ether 3

[admin@mikrotik] > routing bgp instance print [admin@mikrotik] > routing bgp instance set 0 as $=100$ router-id=1.1.1.1

[admin@mikrotik] > routing bgp instance print [admin@mikrotik] > routing bgp peer add remote-as $=200$ remote-address $=10.10 .10 .2 / 30$ [admin@mikrotik] > routing bgp network add network $=10.10 .10 .0 / 30$

b. klik Routing $\diamond$ Bgp. c. Pada table BGP, klik instance. Klik pada kotak sesuai dengan gambar dibawah ini :

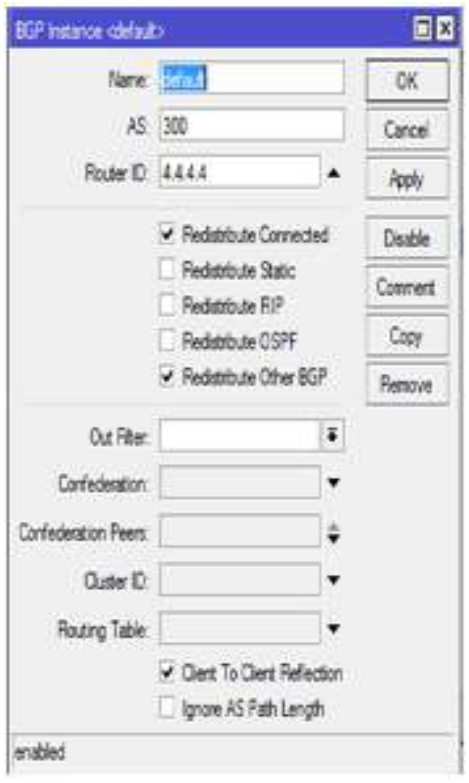

d. Klik peer, isi keepalive time $=255$ 
Fakultas K omputer

\section{TUGAS 1 - 88675543}

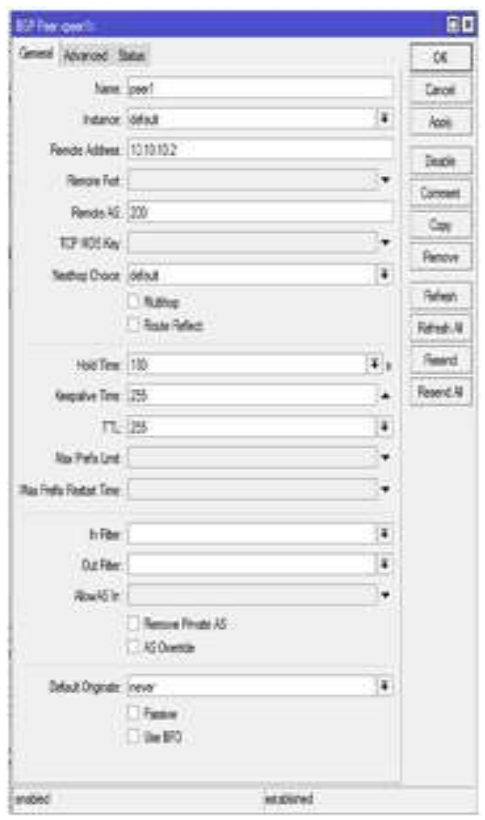

6. a. Konfigurasi di mikrotik Mamay

[admin@mikrotik] > ip address add address $=30.30 .30 .2 / 30$ interface $=$ ether 3

[admin@mikrotik] > routing bgp instance print [admin@mikrotik] > routing bgp set 0 as $=300$ router$\mathrm{id}=4.4 .4 .4$

[admin@mikrotik] > routing bgp instance print [admin@mikrotik] > routing bgp peer add remote-as $=200$ remote address $=30.30 .30 .1 / 30$ [admin@mikrotik] >routing bgp network add network $=30.30 .30 .0 / 30$

b. klik Routing $\diamond$ Bgp. c. Pada table BGP, klik instance. Klik pada kotak sesuai dengan gambar dibawah ini :

\section{Klarisa Anugrah}

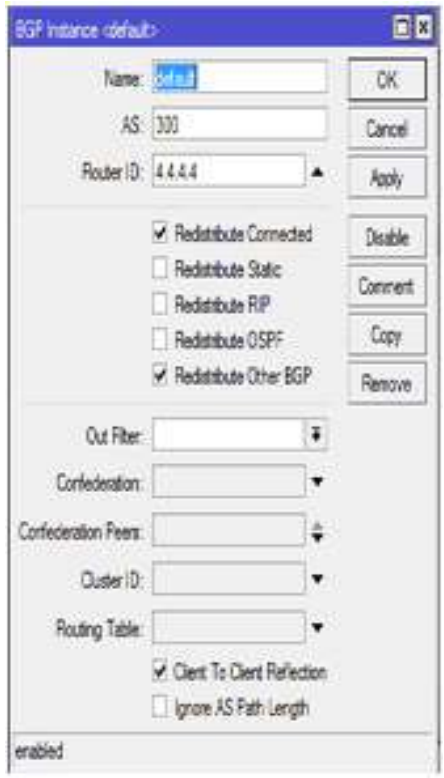

d. Klik peer, isi keepalive time $=255$

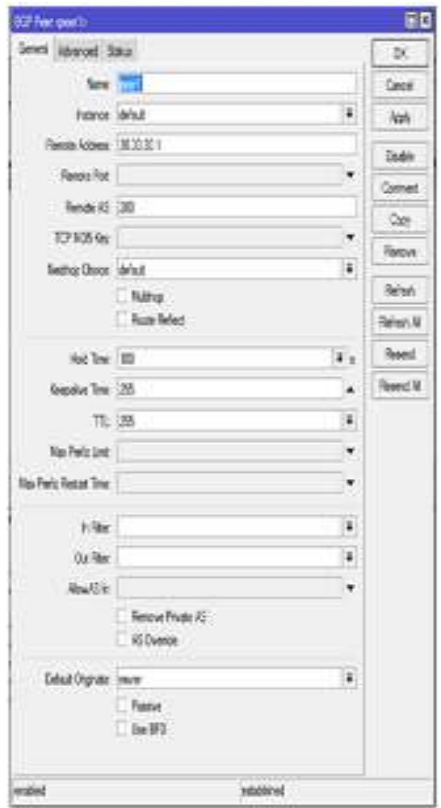

7. a. Konfigurasi di mikrotik Firhan

[admin@ mikrotik] > ip address add address $=10.10 .10 .2 / 30$ interface $=$ ether 3

[admin@mikrotik] > ip address add address $=20 \cdot 20 \cdot 20.1 / 30$ interface $=$ ether 4 


\section{Fakultas Komputer}

\section{TUGAS 1 - 88675543}

[admin@mikrotik] > routing bgp instance print [admin@mikrotik] > routing bgp instance set 0 as $=100$ router-id=1.1.1.1

[admin@mikrotik] > routing bgp instance set 1 as $=200$ router-id=2.2.2.2

[admin@mikrotik] > routing bgp instance print [admin@mikrotik] > routing bgp peer add remote-as $=300$ remote-address $=20.20 .20 .2 / 30$ [admin@mikrotik] > routing bgp peer add remote-as $=100$ remote-address $=10.10 .10 .1 / 30$ [admin@mikrotik] > routing bgp network add network=10.10.10.0/30 [admin@mikrotik] > routing bgp network add network=20.20.20.0/30

b. Klik Routing $\diamond$ Bgp. c. Pada table BGP, klik instance. Ceklis pada Redistribute Connected dan Redistribute Other BGP. d. Klik peer, isi keepalive time $=\quad 255$

8. a. Konfigurasi pada mikrotik Firha

[admin@mikrotik] > ip address add address=20.20.20.2/30 interface $=$ ether 3

[admin@mikrotik] > ip address add

address $=30.30 .30 .1 / 30$

interface $=$ ether 4

[admin@mikrotik] > ip address add address $=40 \cdot 40 \cdot 40 \cdot 1 / 30$ interfac e=ether5 [admin@mikrotik] > routing

\section{Klarisa Anugrah}

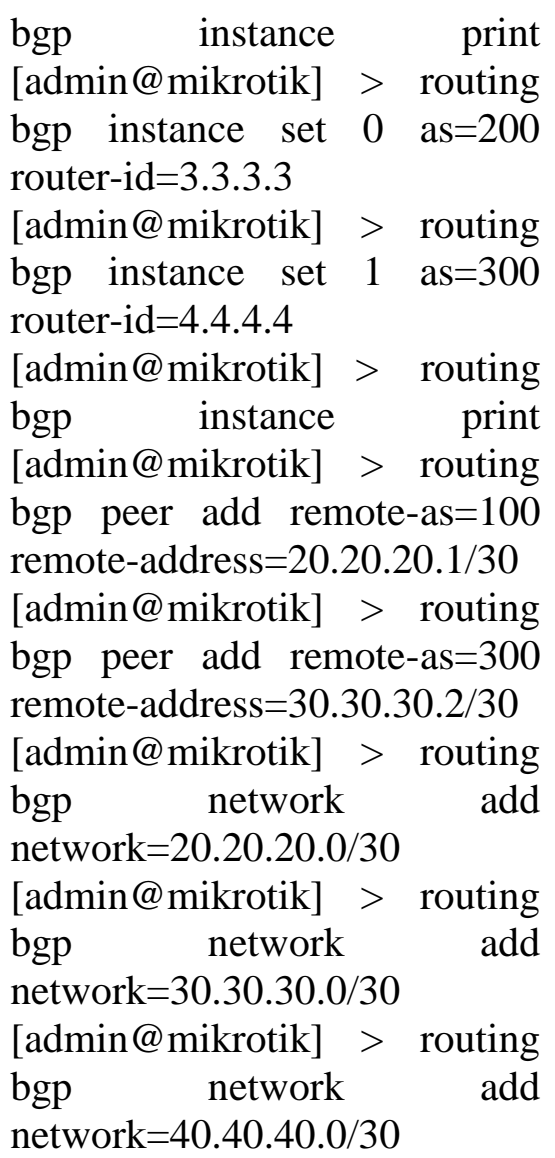

b. Klik Routing $\diamond$ Bgp. c. Pada table BGP, klik instance. Ceklis pada Redistribute Connected dan Redistribute Other BGP. d. Klik peer, isi keepalive time $=255$

9. a. Konfigurasi di mikrotik Angga

[admin@mikrotik] > ip address add address $=40.40 .40 .2 / 30$ interface $=$ ether3

[admin@mikrotik] > routing bgp instance print [admin@mikrotik] > routing bgp instance set 0 as $=200$ router-id=5.5.5.5

[admin@mikrotik] > routing bgp instance print 


\section{Fakultas K omputer}

\section{TUGAS 1 - 88675543}

[admin@mikrotik] > routing bgp peer add remote-as $=300$ remote-address $=40.40 .40 .1 / 30$ [admin@mikrotik] > routing bgp network add network $=40.40 .40 .0 / 30$

b. Klik Routing $\diamond B g p$. c. Pada table BGP, klik instance. Ceklis pada Redistribute Connected dan Redistribute Other BGP. d. Klik peer, isi keepalive time $=$

J. Hasil Percobaan 1. Hasil ping

Dari mikrotik mamay.

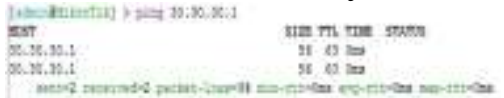

Dari mikotik Ani

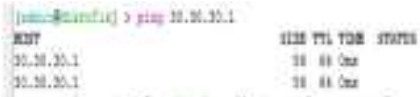

C. ID SECURITY

QWTD4452377-ASP-5244107

D. KESIMPULAN

- BGP (Border Gateway Protocol) adalah sebuah protokol routing interAutonomous System pada internet melalui AS-Path BGP - Peer dikonfigurasi secara manual untuk bertukar informasi routing adalah melalui koneksi TCP kemudian mulai mendengar BGP peer lain. Tidak ada pencari/penentuan informasi pada BGP.

- Untuk bisnis ukuran sedang yang masuk kedalam kategori

\section{Klarisa Anugrah}

BGP biasanya untuk tujuan multi homing jaringan mereka.

E. DISKUSI

Saya bersama teman saya bernama sugeng mendiskusikan tentang Border Gateway Protokol. BGP (Border Gateway Protocol) adalah sebuah protokol routing inter-Autonomous System dan salah satu jenis routing protokol yang banyak digunakan di ISP besar (Telkomsel) ataupun perbankan, Fungsi utama sistem BGP adalah untuk bertukar informasi network yang dapat dijangkau (reachability) oleh sistem BGP lain, termasuk di dalamnya informasi-informasi yang terdapat dalam list autonomous system (AS). BGP berjalan melalui sebuah protokol transport, yaitu TCP. AS (Autonomous System), menurut definisi klasik adalah seperangkat router yang berada di bawah otoritas/administrasi teknis tunggal. Untuk merutekan paket antar-AS internal, kita akan membutuhkan Interior Gateway Protocol. BGP (Border Gateway Protocol) merupakan routing protocol jenis EGP (Exterior Gateway Protocol) . BGP adalah salah satu routing protocol yang menangani jaringan antar AS (Autonomous System). BGP memiliki kemampuan yang sangat handal dengan 
Fakultas Komputer

\section{TUGAS 1 - 88675543}

melakukan pengumpulan rute, pertukaran rute dan menentukan jalur terbaik untuk mencapai tujuan. BGP merupakan metode routing untuk tingkat jaringan yang besar dan rumit yang disetting secara dynamic guna mempermudah dan mempercekat dalam pengkonfigurasiannya. BGP dapat digunakan untuk menghubungkan antar dua organisasi besar yang memiliki AS yang berbeda. Tujuan BGP adalah untuk memperkenalkan pada dunia luar alamat-alamat IP apa saja yang ada dalam jaringan tersebut. Setelah dikenal dari luar, server-server, perangkat jaringan, PC-PC dan perangkat komputer lainnya yang ada dalam jaringan tersebut juga dapat dijangkau dari dunia luar. Selain itu, informasi dari luar juga dikumpulkannya untuk keperluan organisasi tersebut berkomunikasi dengan dunia luar.

\section{F. REFERENCE}

www.google.com

http://jaringankomputer.blogspot.c om/routingbgp. 